OLGA LAVRENOVA

вед.Н.С. ИНИОН РАН

e-mail: olgalavr@mail.ru

\title{
Записные листы Николая Рериха - космическая эссеистика
}

\author{
Abstract \\ Nikolay Roerich's Note Sheets as the Cosmic Essayistics
}

Note Leaves or Diary Leaves by Nicholas Roerich it's a collection of essays, which covered a wide range of issues, from the important events of his time to the cosmic origin of the culture. This is one of the unfairly little-known highly artistic samples of literature, these notes are synthetic in nature, including philosophy and ethics. Most of these essays were published during the life of the artist and the philosopher in American, Indian, Latin American and Manchurian press in context of Roerich's socio-cultural activities, primarily the establishment of The Treaty on the Protection of Artistic and Scientific Institutions and Historic Monuments or Roerich Pact. The essays in fact given the world view in past, present and future.

Keywords: Nicholas Roerich, essays, philosophy of culture.

При ближайшей оказии перешлю в Харбин последние записные листы. Там будет полезно еще раз прочесть о взаимном уважении и дружелюбии, словом, обо всем том, что на всем земном шаре лежит в основе дел.

Н.К. Рерих, Дневник Маньчжурской экспедичии, 13.03.1935 г.

Николай Константинович Рерих - один из ярких представителей плеяды русских мыслителей и художников первой половины XX века. Он был художником, писателем и поэтом, ученым и путешественником, общественным деятелем и мыслителем-космистом. Все грани его творчества были взаимосвязаны. Его живописные полотна являются воплощением его философского мировоззрения, а очерки и стихи можно назвать живописью словами. Историк и археолог, он совершил несколько экспедиций по России, Центральной и Восточной Азии. 
В литературном наследии Рериха особенно выделяются Листы дневника или Записные листы, как он сам их называл - труд, в котором представлен широкий спектр духовно-нравственных, философских и культурологических проблем с привлечением обширного исторического материала. Эссе, затрагивающие разные аспекты культуры, основаны на тонком понимании исторических процессов и перспектив развития, и все они выстроены в соответствии с единой концепцией культуры. Согласно этой концепции, культура - это проявление человеческого духа, и культурное наследие представляет собой созданную в веках лестницу к духовным восхождениям. Культура - не простая совокупность артефактов и текстов, но cult-Ur, «поклонение Свету».

Рерих совершил несколько путешествий. В начале XX века вместе с женой путешествовал «по городам русским», итогами стали многочисленные этюды древнерусских архитектурных комплексов. Два десятилетия позже состоялась грандиозная Центрально-Азиатская экспедиция (1924-1928), которая была организована Музеем Николая Рериха в Нью-Йорке, еще десять лет спустя - экспедиция в Маньчжурию и Внутреннюю Монголию в 19341935 гг. под эгидой Департамента сельского хозяйства США.

Записные листы начали создаваться на маршруте Маньчжурской экспедиции. Оппоненты не раз ставили Н.К. Рериху в вину то, что он, не будучи ботаником, возглавил ботаническую экспедицию. Далеко не все отчеты, направляемые в Департамент, удовлетворяли чиновников, для которых были принципиальны прежде всего финансовые вопросы, например то, что походные сапоги и прочее обмундирование не могут быть оплачены из выделяемых на экспедицию сумм. Все эти бумаги нашли свое место в архивах и там упокоились. А размышления Рериха о геоботанических проблемах, о природе и человеке в их метафизическом единстве остаются до сих пор актуальными и востребованными, поскольку в них заложен эволюционный мировоззренческий потенциал. Для Николая Константиновича это путешествие было новым этапом в его постоянных размышлениях о судьбах человечества и планеты.

Одним из итогов Центрально-Азиатской экспедиции стала книга $A л-$ тай-Гималаи - экспедиционные наблюдения в контексте философской концепции культуры, разработанной Николаем Константиновичем, а также мощные сюжетные полотна и тысячи эскизов, сделанных на маршруте. Во время Маньчжурской экспедиции живописных работ было написано гораздо меньше. Это был период зрелых метаисторических размышлений Мастера, который отражен в литературных очерках Рериха - тех самых 3аписных листах. По свидетельствам очевидцев, Николай Константинович каждый день диктовал новое эссе, удивительное по своей глубине и простоте, часть из них, опубликованная в маньчжурских газетах, составила книгу Мастера Священный дозор (1934).

Планируя в будущем собрать все очерки воедино, Н.К. Рерих пишет:

От издательства при той книге можно включить также следующее: Листы дневника появлялись в различных газетах и журналах Америки, Европы, Индии и Дальнего 
Востока. Некоторые из них являются как бы развитием предыдущей мысли, но издательство сохраняет их под датою дня их написания, что тем более обрисовывает течение мысли автора». При издании книги такое замечание тем более пригодится, что кому-то, может быть, покажется, почему продолжение развития той же мысли входит в разные дни, но сами события или известия прессы или размышления невольно заставляли углублять некоторые положения ${ }^{1}$.

То есть Записные листы этого путешественника и мыслителя, собранные в их целокупности, так же как и тексты философского учения Живой Этики, которая создавалась Рерихами - Николаем и Еленой Рерих, представляют собой энергетическую спираль, при каждом новом витке раскрывающую новые грани той или иной идеи. Эти очерки представляют собой «ту новую литературу, где ощущается дыхание будущей эволюционной эпохи, будущих новых средств выражения и будущей эстетики» ${ }^{2}$. Они выходят далеко за рамки обыденного мышления, раздвигают горизонты и открывают путь к постижению Высшего. Изданные спустя полвека после ухода Н.К. Рериха ${ }^{3}$ (и переизданные пять лет спустя), они сверкают разными гранями познания, передавая всю полноту Мироздания. «Такие понятия как синтез, культура, красота, и особенно искусство, Рерих считал основополагающими эволюционными вехами» ${ }^{4},-$ пишет Л.В. Шапошникова. Он «много писал о синтезе как одном из важнейших направлений современного эволюционного процесса. Он сумел воплотить этот синтез в своих литературных произведениях, где гармонично сочетаются Красота, Знание и Мысль» ${ }^{5}$, воплотить в жизнь идеи Живой Этики о дисциплине и творчестве мышления, его записные листы - пример того, как из грубого субстрата повседневности вырастает цветок огненной мысли, впитывающий лучи дальних миров и иных светил.

В статье Да процветут пустыни, может быть, впервые для общественного сознания был поднят вопрос антропогенного происхождения пустынь и их мелиорации. Переведенный на английский язык, этот очерк произвел чрезвычайно сильное впечатление на президента Рузвельта ${ }^{6}$. В очерке Сад будущего, написанном в Пекине, Рерих снова и снова возвращается к мысли о недопустимости небрежного отношения человека к родной планете:

Конечно, легче не допустить первоначальное заболевание местности, нежели потом бороться с мертвенной стихией. [...] Конечно, не скроем от себя, что нечего только винить козлов и баранов, ибо сами двуногие жестоким и часто бессмысленным истреблением лесов действуют с еще большей вредоносностью. [...] Тем благороднее задача тех правителей, которые стараются предупредить это бедствие человечества и, насколько возможно, залечить раны, причиненные когда-то чьим-то неведением.

${ }^{1}$ Н.К. Рерих, Дневник Маньчжурской экспедищии, Запись от 15.01.35, Москва 2015, с. 127.

2 Л.В. Шапошникова, Врата в будущее [в:] Н.К. Рерих, Листы дневника, в 3 т., т. 1, Москва 1995, c. 23.

${ }^{3}$ Н.К. Рерих, Листы дневника, в 3 т., Москва 1995-1997.

4 Л.В. Шапошникова, Врата в будущее, с. 23.

${ }^{5}$ Ibid., c. 32.

${ }^{6}$ S. Walker, The New Deal, The Guru, and Grass: The Roerich Expedition to Asia, 1934-1936, Отдел рукописей МЦР, Ф.1, Оп. 4, № 528, л.14. 
Конечно, окраинные барханы монгольской Гоби являются наилучшей областью для наблюдения над засухостойкими растениями. Те породы трав и прочей растительности, которые удержались, несмотря на соседство страшных песков Такла-Макана, конечно, представляют из себя достойных пионеров для зарождения растительности в оголенных местах. В этом случае чисто ботаническая задача является и делом гуманитарным в полном его значении (выделено мной - О.Л.) ${ }^{7}$.

Несомненно, что условия Монголии на границе степи и барханной пустыни могут давать множество поучительных примеров. Когда из Гоби, из далекого Такла-Макана приносятся вихрями клубы песка и пыли, иногда можно опасаться, что местная, вообще поздно появляющаяся растительность не выдержит, но любопытно наблюдать, как несмотря на всякие затруднения, трава все же начинает пробиваться 8 .

Не так много разновидностей этих сухостойких трав и кустарников. Очевидно, в веках произошел отбор. В то время как в соседней Маньчжурии, где условия немногим сравнительно отличаются, имеется более восемьсот видов растений, тогда как в барханной Монголии, по-видимому, их не более трехсот ${ }^{9}$.

Водитель экспедиции Н.В. Грамматчиков вспоминает, как на его глазах рождалось очередное эссе. Источником вдохновения могла стать заглохшая машина, «потерявшая искру» - и в очерке, надиктованном тем же вечером, Николай Константинович размышлял об искре духа, без которой не может совершаться ни одно важное дело. Каждое событие становилось отправным моментом для нетривиального ассоциативного ряда и размышлений, имеющих космический размах, выводящих сознание за рамки обыденности.

Спектр тем, затронутых в этих очерках, чрезвычайно широк и злободневен. В них обсуждался и строительный потенциал Маньчжурии и Внутренней Монголии, и основные принципы концепции культуры как почитания Света, и принципы приложения этих идей в жизни каждого дня, и ценность искусства, и, соответственно, значение Пакта Рериха в метаисторической и ближайшей исторической перспективе: «Сперва опознаем и сбережем Культуру, а затем и сами банкноты страны станут привлекательными» ${ }^{10}$ (пророческие слова, если вспомнить, сколько сейчас зарабатывают на культурном туризме некоторые страны).

Пакт Рериха, международный договор о защите художественных и научных учреждений и исторических памятников, подписанный в Вашингтоне 15 апреля 1935 г. двадцать одной страной Панамериканского союза - отдельная тема в Записных листах. Этот договор был подписан благодаря широкому общественному движению, которое инициировали Рерих и его сотрудники. В тридцатые годы XX века по всему миру была развернута целая сеть культурных организаций, объединенных идеей Знамени Мира и друзей Музея Николая Рериха в Нью-Йорке. Многие из них вели серьезную культурно-просветительскую работу, руководствуясь гуманистическим мировоззрением Н.К. Рериха, его проектом создания международного закона

\footnotetext{
${ }^{7}$ Н.К. Рерих, Листы дневника, т. 1, Москва 1995, с. 280.

${ }^{8}$ Ibid., c. 504.

${ }^{9}$ Ibid., c. 504.

${ }^{10}$ Ibid., c. 137.
} 
и общественного движения в защиту культурного наследия. И это движение постоянно подпитывалось статьями и письмами Мастера - о беспрецедентном и определяющем значении культуры в жизни общества, в формировании как национальной идентичности, так и «всечеловечности» любого народа.

Николай Константинович активно направлял деятельность своих единомышленников, вдохновлял их, объясняя основные положения своей философии культуры и конкретные практические действия, необходимые для организации подписания Пакта.

После того как Пакт Рериха был принят и ратифицирован многими из подписавших его государств, в очерках раз за разом обосновывается мысль о том, что такой международный документ не должен быть формальностью. Сам договор не предусматривал никаких санкций за его нарушение. Соответственно, действенной силой, обеспечивающей его соблюдение должно было стать развитие общественного сознания, которое не допустило бы варварских действий со стороны своих правительств. Фактически, перенося ответственность за сохранение культурного достояния с правительств на народы, Рерих писал о высочайшем уровне гражданственности, до которого было очень далеко в его время, и современность не намного приблизилась к этому идеалу.

Во время Маньчжурской экспедиции героями очерков становилась многогранная реальность Азии - и институт Фан Мемориал, и его программа исследований, и «длинное ухо Азии» - информационная проницаемость, казалось бы, безлюдного пространства пустынь, и наполненность этого пространства легендами и таинственными смыслами. Здесь же, на южных окраинах пустыни Гоби, в лагере Тимур Хада, был написан один из самых сакральных записных листов - «Он», о трепетном и торжественном ожидании и предчувствии прикосновения Высшего.

В этих очерках Николай Константинович размышляет также о первопричинах клеветы и злобы, находя ее прежде всего в невежестве, и показывает пути достойного отступления культуры в «катакомбы» под натиском невежества, пришедшего к власти. Духовное творчество, уйдя под давлением обстоятельств в подполье, должно стать еще насыщеннее и напряженнее, выравнивая чаши мировых весов от исторических перекосов. Как показывают письма Н.К. Рериха, очерк Катакомбы был написан именно с учетом ситуации в Харбине.

По завершении Маньчжурской экспедиции работа над Записными листами продолжалась. Более поздние философские эссе еще больше расширяют тематический и географический спектр. Мысль Мастера устремляется в разные уголки земли, где формируется какое-либо строительное начинание или, напротив, где совершаются преступления против человечества и культуры. Мы видим энциклопедический охват проблем и событий, философско-личностное осмысление всего, что происходит в мире. И чем сильнее клубятся тучи в преддверии Второй мировой войны, тем чаще в очерках сквозят тревога, боль и - стоицизм и надежда. На каждую боль мира Рерих отвечает не только сопереживанием, но и твердой верой в грядущую победу гуманизма, 
который должен стать основополагающим качеством человечества. Привести к этому, опять же, могут только культура, красота и искусство. «Красота представляет собой вселенскую гармонию, порядок, само мироздание. Красота - это то, что возникает в результате борьбы Космоса с хаосом и победы первого над последним» ${ }^{11}$.

В очерках великое множество имен, упоминаются современники Рериха - художники, ученые, философы, композиторы, политические деятели. Со многими из них, даже с коронованными особами (например, королем Югославии Александром), художник и мыслитель имел переписку и творческий взаимообмен мыслями. Есть и другие имена - великих мыслителей прошлого, библейских персонажей и великих святых христианской, индуистской и буддийской традиций. Все они вовлечены в единую культурную историю, единую судьбу, сложившую современное человечество. Они люди подвига. Если рассматривать национальную культуру в неразрывной связи с историческими личностями, творившими ее, то, например, культура России в литературном наследии Рериха представляется моноцентричным образованием. Центральная легендарно-историческая личность, на которой держится образ России - Преподобный Сергий Радонежский.

Темой Записных листов становится и такая высокая и, казалось бы, анахроничная категория, как подвиг в контексте сущности бытия современников. На подвиге строятся основные вехи пути восхождения человечества. Эта тема проходит красной нитью в очерках периода Великой Отечественной войны, когда Рерихи из Индии с тревогой и надеждой следили за сводками с фронта.

Bce темы, поднятые в Записных листах, не только не теряют актуальности со временем, но становятся все более злободневными, так как более полувека назад, когда Рерих писал эти эссе, он смог увидеть, описать, оценить зарождение основных проблем человечества и предугадать ход их развития и их трагическую и судьбоносную значимость для будущего народов.

Мозаика очерков создает картину волн истории, то возносящих человечество к высотам духа, то низводящих его в бездны невежества. Рерих «ощущал, как никто другой, единый и целостный процесс движения материи человеческой истории» ${ }^{12}$. Он уже тогда писал об Армагеддоне культуры - как о последней войне духа, в которой решается быть или не быть человечеству. Он размышлял о мученичестве культуры, страдающей от рук современных варваров, а сегодня помимо “тихих погромов” и разрушений во время военных действий добавилась проблема тотальной “варваризации” общества, когда утрачивается сам язык культуры и молодое поколение в основной массе уже не может без специального толкового словаря читать произведения классиков. Более того, в прошлое уходят не только слова, но и многие высокие понятия, которые они обозначали. Культура выхолащивается и «выполаживается» как рельеф древних гор - ее вершины истираются в песок, который отлагается в долинах.

\footnotetext{
11 Л.В. Шапошникова, Bрата в будущеее, с. 24.
}

12 Ibid., c. 20. 
Еще один спектр актуальности Записных листов Рериха - усиление роли Азии в современном мире, которое было им предугадано более полувека назад. Рерих, конечно, учитывал прежде всего духовный аспект, из которого уже проистекают все остальные аспекты жизни. Художник писал о неотъемлемой устремленности западных культур к таинствам Духа, поиску заповедной страны или исконного города Духа в Азии, и о том, что в лучших достижениях западных культур, в том числе русской, прослеживается их связь с Востоком, уходящая в глубь веков, во времена великого переселения народов и монгольского нашествия, докатившегося до границ Европы.

Еще в прошлом веке Рерих писал о наполненности пространства информацией в связи с развитием технических средств цивилизации - тогда он писал о радиоволнах, о их вездесущности, о том, что с их появлением пространство изменяется качественно. Сейчас информационная насыщенность околоземных сфер возросла в несколько порядков, даже безлюдные места пронизаны излучениями благодаря спутниковой связи. Это заботит ученых с точки зрения биологических мутаций под воздействием электро-магнитных волн и полей, но практически никто не ставит вопрос в философском контексте. Обращение к философской эссеистике Рериха позволяет взглянуть на эту проблему комплексно - как не меняя ничего вовне информация искажает саму природу пространства, изначально пронизанного лишь солнечными и космическими лучами, и потому животворящего. Пространство культуры насыщено духовными магнитами храмов и памятных мест, сцементировано преданиями и легендами. Если этот информационный пласт ослабевает - культурное пространство распадается, музеифицируется - становится разрозненным собранием артефактов прошлого, лишенных живой пульсирующей связи, придающей им смысл.

Рерих много писал о русской эмиграции, которая после 1917 года, с одной стороны, обрела характер бедствия, «гуманитарной катастрофы», с другой эта волна, выплеснувшись за пределы России, оплодотворила иные народы новыми духовными силами, породила великие художественные и философские произведения, еще больше раскрывшие творческий потенциал русского народа. Эмиграция рассматривалась им как расширение границ России, обретение русской культурой всемирного масштаба. Эмиграция сродни великому переселению народов, его причины Рерих видел не в поиске новых пастбищ, а в космических веяниях, о чем он не раз писал в своих очерках. Тот же самый процесс охватил Землю в начале XX века: «С 1914 года человечество пришло в космическое беспокойство. [...] Все поднялось. Все поехало» ${ }^{13}$. Переселение народов - это прежде всего энергообмен, который происходит в глобальных масштабах, обусловливая неожиданные и плодотворные сочетания. Сегодня движение людских множеств по лицу Земли вновь начинает обретать характер гуманитарной и социальной катастрофы, и только осмысление ее с точки зрения взаимного обмена энергией культуры может помочь увидеть пути выхода из кризиса.

${ }^{13}$ Н.К. Рерих, Цветы Мории. Пути благословения. Сердиее Азии, Рига 1992, с. 112. 
В изверившемся XX веке очерки не были отвлеченной литературой, они звали к подвигу, давали понимание значения красоты и героизма в жизни каждого дня, указывали путь к духовному совершенствованию. Записные листы отсылались в местные дружественные газеты, а также в США и Индию - для широкого опубликования по всему миру. Так происходило своеобразное напитывание мирового информационного поля энергией огненной мысли Мастера, то самое «цементирование пространства», о котором говорилось в философии Живой Этики. Публикации очерков становились импульсом, благодаря которому в разных странах возникали новые очаги культуры, в свою очередь как магнит притягивающие новых полезных сотрудников.

Очерки Николая Константиновича при всей своей космичности укоренены в русской культуре, им присущ особый интонационный строй с оттенками петербуржской утонченной интеллигентности, впитанной с детства. Написанные вдали от Родины, они, тем не менее, возвращают читателя к историческим корням, лучшим традициям дореволюционной России, сейчас уже невозвратно потерянным, поскольку в прошлом веке ушли из жизни последние носители этой культуры.

И наконец, эссе написаны удивительно богатым и одновременно лаконичным языком, стилистически многообразны - от протокольного языка обращений к высоким собраниям до поэтических описаний и психологических этюдов. В них сконцентрирована, как сжатая пружина, напряженнейшая и тончайшая энергия слова, побуждающая к действию.

По словам наиболее авторитетного рериховеда современности, записные листы Н.К. Рериха «синтетичны в своей изначальной сути и соединяют в себе философию и науку, литературу и широчайший объем знаний духовно-исторических и культурных», они представляют собой «новую литературу, где ощущается дыхание будущей эволюционной эпохи, будущих новых средств выражения и будущей эстетики» ${ }^{14}$.

Это действительно новая эстетика, которая предполагает взаимосвязь красоты мысли и красоты слова, емкую образность и пошаговую, спиральную проработку образов от одного очерка к другому для создания практически голографического эффекта - наличия глубины. Эта та литература, в которой словами создается настроение, передающее трепет невыразимо высоких истин - «светлый вздох о Нереченном» ${ }^{15}$, пробуждающий в сердце читателя тоску о беспредельности. Это та магия творчества, которая может «обратить материю в дух» ${ }^{16}$, условность слова - в путь к первообразу.

\footnotetext{
14 Л.В. Шапошникова, Врата в будущее, с. 32.

${ }_{15}^{15}$ Н.К. Рерих, Листы дневника, т. 1, с. 385.

${ }^{16}$ Ibid., c. 385.
} 


\section{Библиография}

Рерих Н.К., Листы дневника, в 3 т., Москва 1995-1997.

Рерих Н.К., Алтай-Гималаи, Рига 1992.

Рерих Н.К., Письма в Америку (1923-1947), Москва 1997.

Рерих Н.К., Цветь Мории. Пути благословения. Сердце Азии, Рига 1992.

Шапошникова Л.В., Великое путешествие, в 3 кн., Москва 1998-2005.

Шапошникова Л.В., Ученый, мыслитель, художник, Москва 2006.

Lavrenova O., Nicholas Roerich's Central Asian expedition [in:] Proceedings of the $14^{\text {th }}$ International Conference of Historical Geographers, Kyoto 2009, Kyoto University Press, 2010, pp. 85-86.

Nicholas Roerich in Indian Journals (1933-1946), Bangalore 2000.

Walker S., The New Deal, The Guru, and Grass: The Roerich Expedition to Asia, 1934-1936, Отдел рукописей МЦР, Ф.1, Оп. 4, № 528, л. 14. 